\title{
The Marketing of Retirement Communities and Retiree Lifestyles
}

\author{
Susan Lucas, Edinboro
}

\section{Introduction}

Retirement communities not only reflect, reproduce and emplace very specific ideas about how and where to enjoy retirement (Laws 1995; McHuGH 2000), but they are implicated in and are the products of the commodification of later life. As commodities, the effectiveness and therefore the content of advertisements used to attract potential residents play a critical role in promoting the amenities and lifestyle offered by retirement communities. This paper examines the type of images used in the marketing literature, essentially elaborate advertisements, produced by retirement communities in order to promote the lifestyle they offer. As idealized representations of reality these advertisements provide messages and information to older people about the most appropriate way to enjoy later life. The life described champions successful ageing and agelessness while at the same refuting old age and age-related illness. However, as will be shown the representations of reality depicted are not uniform.

\section{Advertisements, Images of Old Age and Retirement Communities}

Following Williamson (1978), Eyles (1987) defines advertisements as signs or representations of reality. SACK (1988: 643) agrees when he defines advertisements as «devices that [enable] individuals to create their own contexts, their own worlds». Just as signs are representations of reality, the contexts depicted by advertisements are also idealized representations of reality. The message provided by the advertisement and understood by those who read it is that the idealized representations of reality shown by the images or text are accessible only through the purchase of the specific commodity on sale (EyLES 1987; SACK 1988). Advertisements therefore link buying commodities to powerful ideas about how to live and identity formation (EyLes 1987). Others argue that advertisements are more than simple messages. Rather advertisements both change and reinforce individual and societal perceptions about social groups, places and the ownership and use of objects (Belk \& Pollay 1985; GerbNER et al. 1986; O'GUINN et al. 1989; LeIss et al. 1990). Thus advertisements can change the reality they represent, the ideas they reproduce and the identities they create.
As representations of reality, as a means by which individual consumers are shown how to create their own worlds, advertisements for retirement communities link very specific ideas about and the images used to describe retirement to the purchase of specific commodities. Rather than being depicted as a time of inactivity, social isolation, destitution and illness, retirement is conceptualized as a time of opportunity, a time to enjoy leisure activities, the company of friends, accumulated wealth and good health (FitzGerald 1985; Laws 1993, 1995; McHugh 2000). EKerdt (1986) suggests that the re-conceptualization of later life as a time to enjoy leisure and social activities provides moral continuity between work and retirement. Advertisements for retirement communities indicate that in order to maintain that continuity it is necessary to move to a retirement community. The re-conceptualization of retirement is therefore emplaced in retirement communities. The re-conceptualized emplaced retirement lifestyle describes later life, mature adults and the age-segregated environments they inhabit with positive images that suggest vitality, activity and wealth.

According to Nussbaum et al. (1989) the use of positive imagery in advertisements that sell goods to the older population communicates positive ideas about later life; thus encouraging among other things successful adaptation to old age. Activity Theory suggests that successful ageing involves the maintenance of «activity patterns and values typical of middle age» (Atchley 1980:239), including levels of physical activity, the preservation of family and social roles and consumption levels. Cole (1992) argues that through the popularization of successful ageing the ageing industry has been able to convince older and younger populations alike that successful ageing can be achieved through the attainment of material possessions. Recognition of the mature population as a substantial and relatively under-exploited market segment in turn has lead to the use of an ever increasing number of positive images to portray old-age in order that a wide range of goods and services can be sold to that population (Featherstone \& Hepworth 1995; Sawchuck 1995; Moschis et al. 1997; LoNG 1998).

Retirement communities are very much part of the ageing industry (Laws 1995; McHugh 2000). Retirement communities are not only residential landscapes created in response to changing demand, but are also the deliberate creations of developers and marketers. According to ZUKIN (1998: 825) the construction and marking of specific, multiple identities and the growth 
and increased visibility of specific groups including the elderly has produced a number of highly visible, highly differentiated «spaces of consumption». Individually and collectively spaces of consumption reflect new patterns of leisure, consumption and cultural production that disguise the ultimate purpose of generating profit through the consumption of space and the creation and promotion of certain identities and lifestyles. As spaces of consumption, retirement communities of all sizes reflect to some degree the association of successful ageing with consumption.

As deliberate creations of the ageing industry, as spaces of consumption produced with the intention of encouraging consumption through the provision of a retirement lifestyle and a space in which to enjoy it, the success of retirement communities rests partially on the promotion of this emplaced lifestyle. The images employed to sell this lifestyle and the space in which it is emplaced are therefore crucial. The purpose of this study is to present a preliminary analysis of the images that are used to sell retirement communities and the lifestyle they offer mature adults.

\section{Methodology}

\subsection{Data}

The data for this study consists of marketing and promotional literature describing a self-selecting sample of eight retirement communities currently located in and around Kitchener-Waterloo, Ontario (Fig. 1). It is argued that the marketing literature provided by retirement communities is equivalent to an advertisement in that it describes a product that is for sale. The only differences between the brochures analyzed and traditional advertisements are length and complexity.

\section{Retirement communities are defined as}

«aggregations of housing units with at least a minimum level of services planned for older people who are predominately healthy and retired» (HunT et al. 1983: 4).

Based on the number and variety of services provided for residents HuNT et al. (1983) subdivides retirement communities into three groups: retirement new towns, retirement villages and retirement subdivisions. The study sample includes six retirement villages, one subdivision and one continuing care facility.

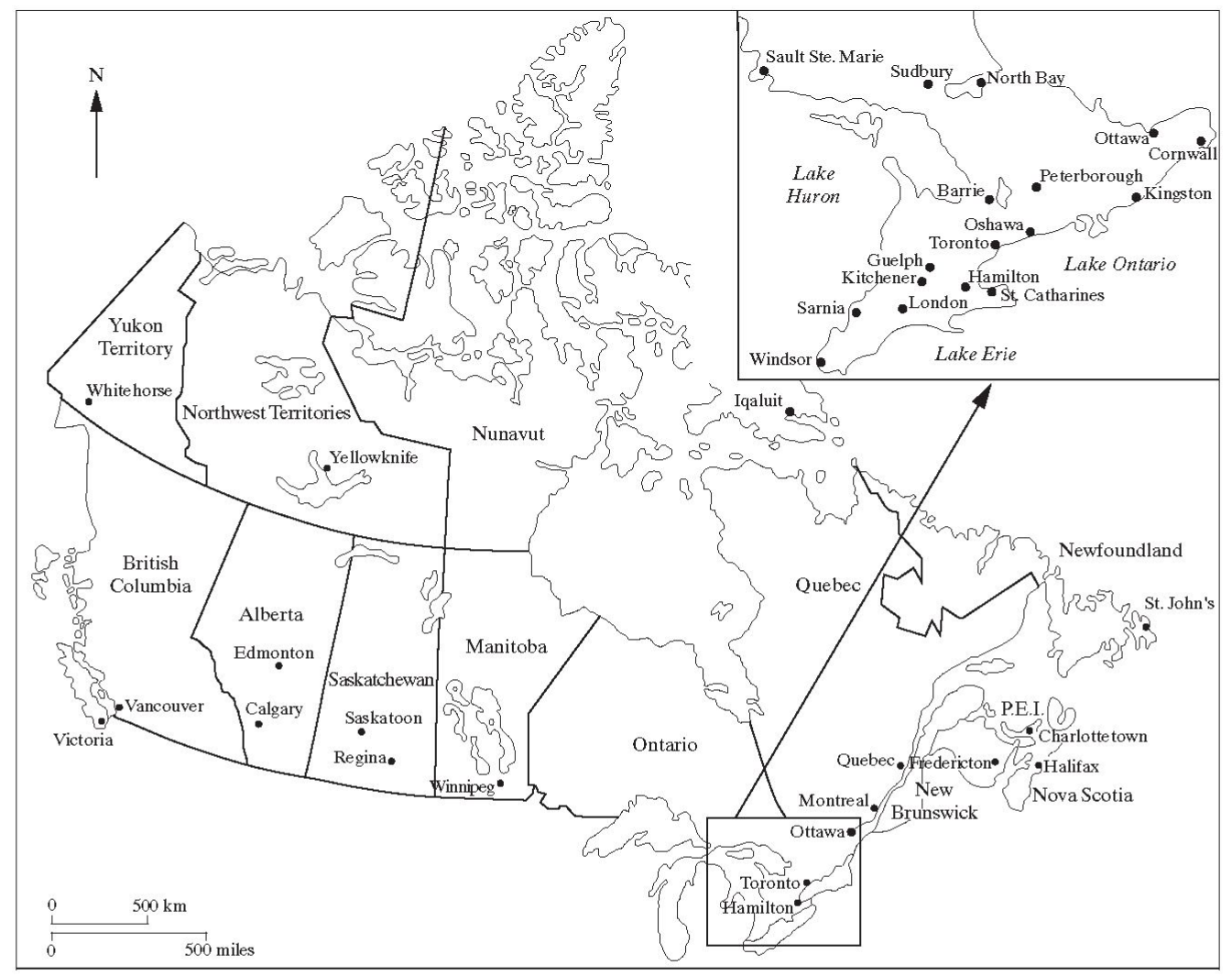

Fig. 1: Map showing location of Kitchener-Waterloo, Ontario

Die Lage von Kitchener-Waterloo, Ontario

Localisation de Kitchener-Waterloo, Ontario

Cartography: L. BAUMANN 
Retirement villages offer residents a wide range of recreational facilities, whereas the assortment of recreational amenities provided by retirement subdivisions is often restricted to a clubhouse (Hunt et al. 1983). Housing options are greatest in retirement villages and may include both owned and rented dwellings, single-family homes and apartments; they are considerably more limited in subdivisions where it is usual to find only one type of dwelling. Support or medical services are not usually provided in either retirement villages or subdivisions. Continuing care communities are defined as facilities that are designed to provide different levels of care and support in one location. Care options available range from help with housekeeping and medication administration to complete

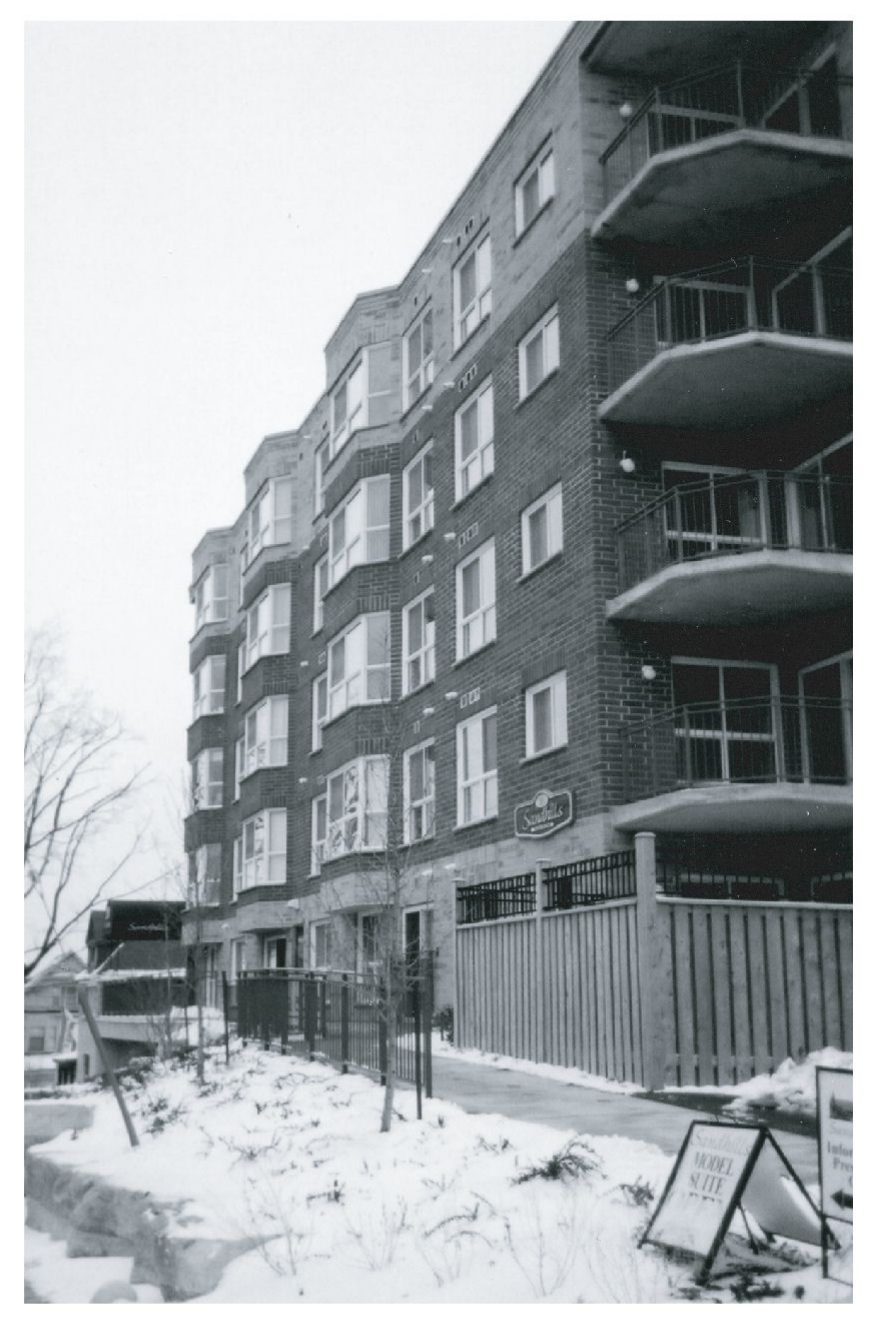

Fig. 2: An example of a non-profit retirement community

Beispiel einer gemeinnützigen Rentnersiedlung

Un exemple de communauté de retraite sans but lucratif

Photo: S. LuCAS institutionalized care in a nursing home. Four of the retirement villages in the sample are owned and operated by faith-based nonprofit consortia (Fig. 2). The mandate of these communities is to provide reasonably priced accommodation and limited care services. The two remaining retirement villages, the continuing care facility and retirement subdivision are managed by for-profit companies (Fig. 3).

The information analyzed includes packages describing the layout of each community, nearby facilities and amenities and community newsletters. Also included in the analysis are newspaper articles contained in community information packages. The content of dwelling floor plans, dwelling and lot price lists and future construction blueprints are not analyzed. The average number of words contained in the promotional pamphlets is 864 .

\subsection{Analysis}

Unlike most studies (Peterson 1992; Zhou \& Chen 1992; LANGMEYer 1993; RoberTs \& Zhou 1997) of the images used to represent older adults in advertisements, descriptive content analysis is used to code the text of the retirement community marketing literature. It was not possible to assess the content of the pictorial images used for the following reasons: (1) some brochures contained only text, (2) many of the images used were drawings of future facilities, and (3) some of the images used were generic and did not depict dwellings or facilities available in a specific community. Although unusual it should be remembered that any analysis of the textual descriptions used in retirement community brochures should yield similar results to an analysis of the pictorial images used because both express the same society-wide sentiments about later life and retirement.

In order to analyze the types of images used to promote retirement community living, each sentence or phrase is classified into one of three categories: successful ageing, the physical aspects of community and age-related decline. A sentence or phrase that implies successful ageing is classified under the first heading: successful ageing. Successful ageing is suggested by sentences that refer to family and social roles, as well as activities that conjure up images in keeping with the idea of forestalling old age. Text depicting residents participating in group fitness activities, playing golf or tennis or shopping are examples. Sentences describing the location of the dwellings for sale and available on-site amenities are classified in a second category: physical aspects of the community. Images that indicate that the physical deterioration associated with increasing age cannot be avoided are classified under the heading «age-related decline». References to the availability of on-site medical services, intercom sys- 


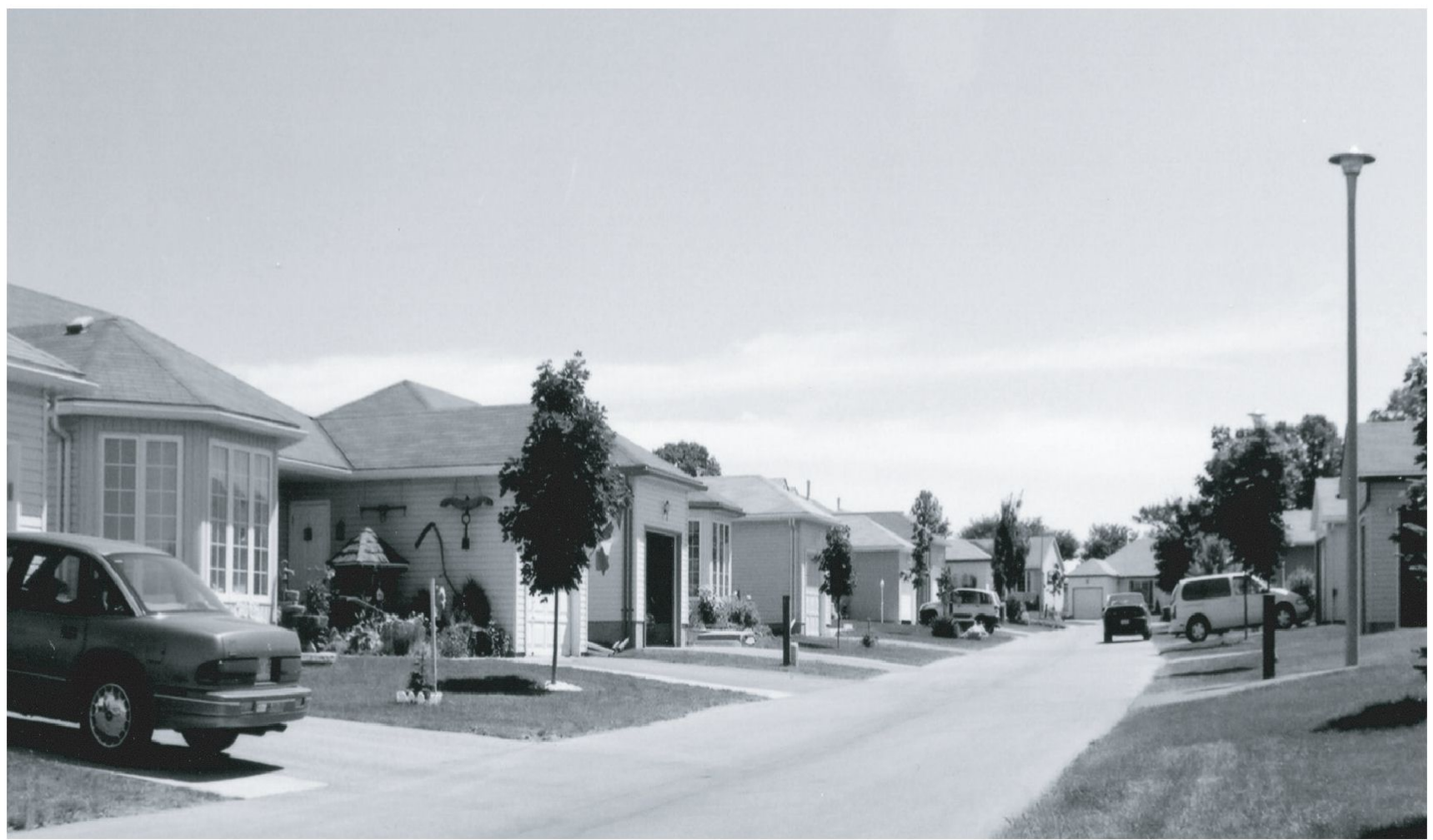

Fig. 3: Examples of the housing typically available in for-profit communities Typische kommerzielle Rentnersiedlung

Exemples de logements disponibles dans les communautés à but lucratif Photo: S. LuCAS

tems designed to summon help, wheelchair accessible bathrooms and the provision of secure nursing facilities are included in this category. If the impression created by the sentence is unclear or irrelevant the sentence is classified in a final category: ambiguous.

In order that conclusions can be reached regarding the importance of each image, the number of phrases classified in each category is calculated (KRIPPENDORF 1980; RIFFE et al. 1998). The relative frequency of phrases describing each image is then calculated for three types of retirement communities: nonprofit, for-profit and continuing care facilities. To meet the requirements of objectivity suggested by BERELSON (1952) and systematization stipulated by KASSARJAN (1977) the text was coded by four different coders on four separate occasions. To ensure that the descriptions of the coding categories were applied consistently all four coders were asked to analyze one pamphlet. The classification results were discussed and any inconsistencies resolved. The results of this sample content analysis were not included in the reported results. All four individual content analyses were then added together and the total results reported.

\section{Results}

The results of the content analysis are shown in Table 1 . The number of communities in each category is given in brackets. Of the three categories used to classify the text, Table 1 shows that descriptions of the physical features of retirement communities, the dwellings for sale, recreational facilities offered and the layout of the community account for nearly half of all the enumerated sentences. Images that epitomize successful ageing i.e., maintaining the values and activity levels of middle age, are the second most numerous (Table 1). Finally, images that indicate that the physical decline associated with increasing age cannot be avoided occur with a frequency of ten percent.

When the results are broken down by type of community, Table 1 shows that in all three types of communities phrases that describe the physical features of the community comprise the greatest proportion of enumerated sentences. Textual descriptions that suggest retirement community residents are physically active, socially integrated, busy and healthy, or have successfully aged, are the next most frequently enumerated 


\begin{tabular}{|l|c|c|c|c|}
\hline & Successful Aging & $\begin{array}{l}\text { Physical Aspects of } \\
\text { the Community }\end{array}$ & Age-related Decline & Ambiguous \\
\hline $\begin{array}{l}\text { Continuing Care } \\
\text { Community (1) }\end{array}$ & 24 & 38 & 29 & 8 \\
\hline $\begin{array}{l}\text { For-profit } \\
\text { Communities (2) }\end{array}$ & 30 & 53 & 3 & 13 \\
\hline $\begin{array}{l}\text { Non-profit } \\
\text { Communities (5) }\end{array}$ & 30 & 46 & 9 & 16 \\
\hline All Communities (8) & 29 & 48 & 10 & 14 \\
\hline
\end{tabular}

(The names of all the retirement communities who provided information have been changed. Further details are available from the author.)

Tab. 1: The use of images for selling retirement communities

Der Gebrauch von Bildern als Verkaufsanreiz für Rentnersiedlungen

L'utilisation des images pour la vente de communautés de retraite

in for-profit and nonprofit communities. Only a very small proportion of the sentences found in the brochures describing for-profit and nonprofit communities refer to the physical and mental decline that often accompanies increasing age. In the continuing care community, references to age-related decline outnumber references to successful ageing, but not references to descriptions of the physical characteristics of the community.

\section{Discussion}

If as suggested (EYLES 1987; SACK 1988) advertisements are idealized representations of reality that show consumers which clothes to wear, which cars to drive and which houses to buy in order that they can live the ideal life depicted; then the advertisements used to sell retirement communities depict an idealized world for retirees characterized by the promotion of successful ageing and the denial of old age and age-related chronic illness; described by an abundance of positive imagery. However, the representations of reality depicted vary. This variation produces different idealized worlds that reflect, to a greater or lesser extent, the denial of old age and age-related illness as well as the promotion of successful ageing.

The first element of the idealized worlds created by the retirement community marketing brochures is the physical settings of each community. In general, retirement communities are depicted as problem-free insulated landscapes that provide mature adults with the opportunity to reflect on life:

«Imagine yourself in the centre of a traditional European town square ... a clock tower with a fountain at the base faces the elegant buildings ... Waterloo Square is not a place to meet friends but also a place for quiet relaxation and mediation it is a place to celebrate life» (Waterloo Village Retirement Community).

Furthermore the landscapes of retirement communities are landscapes of leisure and consumption, not of production. Just as the pursuit of a leisure-filled retirement represents the continuation of what EKERDT (1986: 240) calls the «busy ethic» the creation of specific landscapes in which to pursue that lifestyle and associated consumption mirrors the construction and continual adaptation of landscapes that support production. Thus detailed lists about on-site and nearby leisure facilities are provided in all the marketing pamphlets analyzed. The information provided about onsite leisure amenities is particularly detailed for forprofit communities located in rural areas:

«there is an indoor swimming pool, a sauna, whirlpool, exercise gym, a crafts studio, a library as well as meeting and party rooms ... there is a lake on the property for fishing and boating and avid hikers will certainly enjoy the wooded trails ... if golf is your passion, then you only need to walk next door» (pamphlet from Village on the Green Adult Lifestyle Community).

In comparison details about on-site recreational facilities in the nonprofit communities and the retirement subdivision included in the sample are limited:

«pamper yourself in the heated indoor barrier-free swirl pool or exercise in the fitness area» (pamphlet from Waterloo Village Retirement Community).

As well as providing potential residents with useful information, constant references to the physical features of a community also emplace notions of successful ageing and agelessness in retirement communities by associating specific behaviors and attitudes with well-defined spaces. Because ageing is an emplaced 
process and retirement communities are distinct identifiable spaces, one of the most frequently discussed physical aspects of community is location. Discussions of location in general emphasize accessibility, ruralness and separateness. However variation exists between rural and urban communities in the exact locational attributes discussed. Descriptions of communities constructed in the countryside emphasize ruralness and proximity to, but separateness from nearby towns. For example the text describing the location of one community declares that it

«is nestled in an area which the Mennonite settlers referred to as 〈little paradise〉... [that] still consists of rolling fields, fertile plains, majestic trees» (pamphlet from Village on the Green Adult Lifestyle Community).

The proximity, but separateness, of another community from nearby urban areas is described thus:

«Summerside is just minutes from downtown New Hamburg. It is also a short drive to Kitchener-Waterloo» (pamphlet from Summerside Retirement Community).

In contrast, descriptions of the locations of urban retirement communities emphasize accessibility:

«in the heart of Uptown Waterloo, Waterloo Village provides you easy access to all amenities ... a shopping mall ... a world class recreation centre ... a 125 acre park with walking trails and tennis courts ... convenient bus service allows access to fine restaurants, shopping opportunities and hospitals» (pamphlet from Waterloo Village Retirement Village).

While describing the physical aspects of an individual community serves to attract potential residents, the same text also simultaneously helps promote successful ageing and the concomitant denial of old age and age-related illness. By combining basic information about on-site swimming pools, fitness facilities, hiking trails and various games with descriptions of residents participating in these activities, successful ageing is subtly suggested. For example the following quote indicates older adults are healthy, active, have friends and are involved in the community:

«you can also relax on the large outdoor patio, take a refreshing dip in the heated pool, work-out in the exercise room or enjoy a friendly game of billiards, darts or shuffleboard» (pamphlet from Summerside Retirement Community).

As these quotes from nonprofit communities show:

«settle down with a good book in the library ... tend your garden ... watch children at the day-care centre» (pamphlet from Waterloo Village Retirement Community) and

«with opportunities to socialize with like minded friends and the assurance of personal support services when needed» (pamphlet from River View Retirement Community), subtle, yet distinct differences exist in how successful ageing is promoted in nonprofit compared to for-profit communities. Although older adults are still seen as active and involved with their families, the text contained in brochures depicting nonprofit communities suggests that residents participate in more sedate activities. In the second quote one aspect of successful ageing, socializing, is linked, through residence in a specific retirement community, to the need for support services. This suggests that while the residents may be ageing successfully this will not always be the case.

In keeping with the promotion of successful ageing, the physical and mental decline that usually accompanies old age is almost totally denied in the text describing for-profit communities and only indirectly referred to in the brochures describing the nonprofit communities. In the for-profit communities the only acknowledgement of old age-related illness occurs through references to nearby health care facilities. In nonprofit communities references to illness are framed in the context of «ageing-in-place and the availability of housekeeping and medical support services that allow residents to maintain their independence

«with the assurance of personal support services if needed ... in-suite nursing support and 24 hour emergency assistance are available» (pamphlet from Waterloo Village Retirement Community).

As illustrated by this quote from a nonprofit community references to age-related illness and the loss of physical capabilities is also manifest through references to home design

«all homes are designed to be barrier free, with wide doorways ... lower counters and cabinets, roll-out drawers ... bathrooms feature one-piece tubs and showers ... safety grab bars ... and showers are oversize to include seats» (pamphlet from River View Retirement Community).

However, while frequent in the marketing material describing nonprofit communities and the continuing care facility, such references are totally absent from pamphlets produced by for-profit communities. Only in the continuing care facility are direct references made to old age-related illnesses, particularly degenerative mental disorders.

The way to achieve successful ageing is through consumption. Consumption in retirement is represented most directly by home ownership and the ability to afford a dwelling in a retirement community. In the marketing literature for nonprofit communities considerable emphasis is placed on describing the type of home ownership offered and the guarantees it provides residents in terms of access to care services and preventing loss of equity:

«River View makes [selling your current home] easy by providing a high quality of life with no loss of independence plus future support services - while preserving the equity people have worked a lifetime to build up» (pamphlet from River View Retirement Community). 
In contrast, home ownership and consumption in forprofit communities are linked to the ability to afford a new dwelling at retirement and participation in the community:

«Homes at Village on the Green are freehold condominiums, which means you own your house and lot ... while the common areas are managed by a condominium corporation in which every homeowner will have a say» (pamphlet from Village on the Green Adult Lifestyle Community).

Access to services is again a concern but unlike in nonprofit communities the emphasis is on access to maintenance services:

«this unique residential community offers [the] quiet advantage of lawn maintenance and snow removal» (pamphlet from Meadow Lane Retirement Community).

More indirect references to consumption are made through descriptions of nearby shopping malls, fine dining establishments and entertainment facilities as well as trips residents can take. For example:

«Kitchener has a world renowned symphony and a wonderful arts facility ... the Waterloo and Princess cinemas preview everything from current releases and foreign films to an award winning commercial festival ... Waterloo offers diners a great choice in fine dining ... Janet Lynn's Bistro or Krebs» (pamphlet from Village on the Green Adult Lifestyle Community).

Underlying such descriptions is the assumption that retirement community residents can afford fine dining, the symphony and other forms of entertainment.

\section{Conclusions}

The purpose of this study was to present an exploratory examination of the promotional brochures used to sell retirement communities. As examples of advertisements the retirement community marketing brochures construct an ideal reality that is available only to residents. As products of the ageing industry this material promotes specific views about later life and appropriate spaces in which to spend it. While qualitative research (Laws 1995; McHugh 2000) based on interviews, participant observation and landscape interpretation has clearly established that notions of successful ageing and agelessness underpin and are reproduced by retirement communities, the analysis of the advertisements presented in this paper examines how ideas about successful ageing and the concomitant denial of old age are packaged in order to sell a product: retirement communities.

The results show that the advertisements produced by retirement communities on the one hand fulfill a practical need to inform potential residents about available facilities and housing options while on the other they describe an idealized reality that promotes successful ageing and agelessness through elaborate descriptions of residents playing golf, enjoying time with friends and partaking of local cultural amenities. Thus basic information about individual retirement communities is intermixed with subtle messages about how to age successfully and avoid old age. By locating their narratives in specific, well-defined and exclusive spaces, retirement communities emplace ideas about successful ageing.

While the imagery used to describe life in retirement communities suggests a strong belief in successful ageing, the results of the analysis indicate variation in the extent to which the idealized reality portrayed in retirement community marketing brochures reflect notions of successful ageing and the concomitant denial of old age and age-related illness. Successful ageing is most completely embraced in the text describing forprofit communities. Discussions of successful ageing, while evident in the promotional brochures written by nonprofit and continuing care communities, imply less activity and participation in less strenuous activities. References to age-related decline, loss of independence and chronic illness are nevertheless indirect even in these communities.

\section{References}

Atchley, R.C. (1980): The Social Forces in Later Life. - Belmont, California: Wadsworth.

Belk, R.W. \& R.W. Pollay (1985): Images of ourselves: The good life in Twentieth Century advertising. - In: Journal of Consumer Research 11: 887-867.

Berelson, B. (1952): Content Analysis in Communications Research. - Glencoe, Illinois: The Free Press.

Cole, T.R. (1992): The Journey of Life: A Cultural History of Aging in America. - Cambridge: Cambridge University Press.

EKERDT, D.J. (1986): The busy ethic: Moral continuity between work and retirement. - In: The Gerontologist 26: 239-244.

EyLEs, J. (1987): Housing advertisements as signs: Locality creation and meaning-systems. - In: Geografiska Annaler: Series B Human Geography 69: 93-105. Featherstone, M. \& M. Hepworth (1995): Images of positive aging: A case study of Retirement Choice magazine. - In: Featherstone, M. \& A. Wernick (eds): Images of Aging: Cultural Representations of Later Life. - London: Routledge: 29-47.

FitzGerald, F. (1986): Sun City - 1983. - In: FitzGerALD, F. (ed.): Cities on a Hill. A Journey Through Contemporary American Cultures. - New York: Simon and Schuster: 203-245.

Gerbner, G., Gross, L., Morgan, M. \& N. Signorielli (1986): Aging with television: The dynamics of the cultivation process. - In: BrYANT, J. \& D. Zillman (eds): 
Perspectives on Media Effects. - Hillsdale, New Jersey: Lawrence Erlbaum: 17-40.

Hunt, M.E., Feldt, A.G., Marans, R.W., Pastalan, L.A. \& K.L. VAKALO (1983): Naturally occurring retirement communities. - In: Journal of Housing for the Elderly 1: 3-21.

KassarJian, H.H. (1977): Content analysis in consumer research. - In: Journal of Consumer Research 4: 8-18. KrIPPEndorfF, K. (1980): Content Analysis: An Introduction to its Methodology. - London: Sage Publications.

LANGMEYER, L. (1993): Advertising images of mature adults: An update. - In: Journal of Current Issues in Advertising 15: 81-91.

LAws, G. (1993): «The land of old age»: Society's changing attitudes toward built environments for elderly people. - In: Annals of the Association of American Geographers 83: 672-693.

LAws, G. (1995): Embodiment and emplacement: Identities, representation and landscape in Sun City retirement communities. - In: International Journal of Aging and Human Development 40: 253-280.

Leiss, W., Kline, S. \& S. Jhally (1990): Social Communication in Advertising. - Scarborough, Ontario: Nelson.

LoNG, N. (1998): Broken down by age and sex: Exploring the ways we approach the elderly consumer. - In: Journal of Market Research 40:73-91.

McHugh, K.E. (2000): The «ageless self»? Emplacement of identities in Sun Belt retirement communities. - In: Journal of Aging Studies 14: 103-115.

Moschis, G., Euehun, L. \& A. Mather (1997): Targeting the mature market: Opportunities and challenges. - In: Journal of Consumer Marketing 14: 282-294.

Nussbaum, J.F., Thompson, T. \& J.D. Robinson (1989): Communication and Aging. - New York: Harper and Row.

O'Guinn, T., Faber, R., Curias, J. \& K. Smith (1989): The cultivation of consumer norms. - In: ScRULL, T.K. (ed.): Advances in Consumer Research. - Volume 16, Provo, Utah: Association for Consumer Research.

Peterson, R.T. (1992): The depiction of senior citizens in magazine advertisements: A content analysis. - In: Journal of Business Ethics 11: 701-706.

RifFe, D., Lacy, S. \& F.G. Fico (1998): Analyzing Messages: Using Quantitative Content Analysis in Research. - New York: Lawrence Erlbaum Associates.

RoberTs, S.D. \& N. Zhou (1997): The 50 and older characters in the advertisements of Modern Maturity: Growing older, getting better? - In: The Journal of Applied Gerontology 16:208-220.

SACK, R.D. (1988): The consumer's world: Place as context. - In: Annals of the Association of American Geographers 78: 642-664.

SAwchucK, K.A. (1995): From gloom to boom: Age, identity and target marketing. - In: Featherstone,
M. \& A. Wernick (eds): Images of Aging: Cultural Representations of Later Life. - London: Routledge: 173-187.

Williamson, J. (1978): Decoding advertisements: Ideology and meaning in advertising. - London: Marion Boyars.

Zhou, N. \& M.Y.T. Chen (1992): Marginal life after 49: A preliminary study of the portrayal of older people in Canadian consumer magazines. - In: International Journal of Advertising 11: 343-354.

ZuKIN, S. (1998): Urban lifestyles: Diversity and standardization in spaces of consumption. - In: Urban Studies 35: 825-836.

\section{Summary: The Marketing of Retirement Communi- ties and Retiree Lifestyles}

Retirement communities offer the promise of a fulfilling life in old age. Purposefully planned and constructed with the intention of encouraging consumption through the promotion of successful ageing and a space in which to enjoy it, the success of retirement communities rests partially on the images used in attendant advertisements. Using content analysis to analyze the text of informational brochures provided to potential residents, this paper examines the images used to sell retirement communities. The sentences are classified into one of three categories: successful ageing, physical attributes of the community and old age related decline.The results show the overwhelming use of positive images to describe retirement community living and a denial of old age related physical decline. Most of the sentences in the brochures relate to the availability and plethora of leisure amenities in retirement communities, or endorse the idea of successful ageing by describing residents as active, healthy individuals with money to spend.

\section{Zusammenfassung: Die Vermarktung von Alterssied- lungen und Lebensstilen von Senioren}

Rentnersiedlungen versprechen einen erfüllten Lebensabend an einem erholsamen Ort. Gezielt geplant und geschaffen, um dieses Bedürfnis zu wecken und kommerziell zu befriedigen, verdanken diese Siedlungen ihren Erfolg zum großen Teil den dabei in der Werbung zum Einsatz gebrachten Bildern. Die in diesem Artikel verwendete methodische Inhaltsanalyse der Texte der an potentielle Kunden verteilten Informationsbroschüren klassifiziert Sätze nach drei Kategorien: successful ageing, die physischen/ infrastrukturellen Qualitäten der Siedlung und altersbezogene Schwierigkeiten. Dabei werden die als Verkaufsanreiz gebotenen sprachlichen Bilder untersucht. Als Ergebnis lässt sich eine übermäßige Verwendung positiver Vorstellungen vom Leben in einer Rentnersiedlung bei gleichzeitigem Negieren physischer Altersprobleme feststellen. Die Mehrzahl der Sätze 
in den Broschüren bezieht sich auf das Vorhandensein und die Vielfalt von Freizeiteinrichtungen in den Siedlungen oder untermalt die Idee des successful ageing, indem sie die Bewohner als aktive, gesunde und kaufkräftige Individuen darstellt.

\section{Résumé: Le marketing des résidences pour personnes} âgées et des styles de vie pour seniors

Le succès des communautés de retraite s'explique partiellement par les images utilisées dans la vente de ce genre de logements. La promotion commerciale qui en est faite insiste sur la notion de «vieillesse réussie» dans un environnement approprié. La contribution se propose d'analyser, dans le contexte canadien, le contenu de certaines brochures promotionnelles fournies aux résidents potentiels. Trois catégories ont servi à l'analyse: celle du «vieillissement réussi», celle de l'environnement physique de la communauté et celle du «déclin» lié au vieillissement. Les résultats montrent que les brochures utilisent préférentiellement des images positives pour décrire la vie de la communauté de retraite, alors qu'elles ignorent les aspects liés au déclin des fonctions physiques des individus. L'accent est mis sur les avantages du lieu de retraite et l'abondance d'équipements de loisirs qui y sont liés. Ils insistent sur le fait que les résidents y sont non seulement des individus actifs, mais également des consommateurs.

\section{Teaching of Geography - relevant questions}

- What are retirement communities?

- List the general ideas about old age communicated by advertisements?

- How are consumption, successful ageing and retirement communities linked?

- Describe the images and ideas used in retirement community advertisements?

- How do the images and ideas used in retirement community advertisements vary?

- What are the differencies between the adverts of profit and non-profit organisations?

- How might the images used to describe retirement communities and retirement community residents vary from images used to depict older people in the general media (magazines, television)?

Susan Lucas, Ph.D., Assistant Professor, Department of Geosciences, Edinboro University of Pennsylvania, 230 Scotland Road, Edinboro, PA 16444. U.S.A.

e-mail: slucas@edinboro.edu

\section{Manuskripteingang/received/manuscrit entré le} 28.3.2004

Annahme zum Druck/accepted for publication/accepté pour l'impression: 1.12.2004 